\title{
Impacts of Urbanization Rate and Land Cover Change on Urban Farm Land A Case of Wolayta Zone Sodo Zuria Woreda
}

\author{
Bereket Geberselassie Assa \\ Collage of Engineering department of Civil Engineering, Wolayta Sodo University, PO box 138, Wolayta, \\ Ethiopia
}

\begin{abstract}
The effect of human intervention on the agricultural system has shown food insecurity with an increase in the cost of crop production in the local market due to the expansion of urbanization in the study area with $2.66 \%$ in 9 years for the demand of residential land. and also beyond this simulation result, the impact of deforestation on urban Agricultural and livelihoods was not scientifically studied in most of the southern Ethiopia high lands and their surrounding in particularly for Wolayta zone sodo zuria woreda has shown $0.295 \%$ per year of forestland declined by $0.09 \%$ for residential land and it has used for public service during the selected study period. This study has focused on the impact of urbanization rate and land use land cover change detection analysis using Primate and secondary data source with integration (GIS) Geographic Information System and Remote sensing Method for managing the negative impact on the geospatial environment in the context of Ethiopian Agricultural Transformation (ATP) goal of sustainable development. And evaluation of image classification accuracy can be defined as the process of comparing the classified image with geographic data considered to be accurate and referential typically, the data which is classified image is compared to are ground-truth based on supervised classification with (CR) Consistency Ratio $0.016 \%$ of the pixel has resulted for accuracy assessment of 30m Land Sat 7 satellite image. In general, a set of reference shapefile has been overlaid as 7 major landuse class which are generated over the classified image by the AHP method of Computing Eigenvector Matrixes, which is an output of the pairwise comparison matrix to produce the best fit set based on the pixel value landuse area listed
\end{abstract}

Keywords: Analytic Hierarchical Process (AHP), Geographic Information System (GIS), Land sat 7 (ETM+) and Eigenvector Matrixes

DOI: $10.7176 / \mathrm{CER} / 13-3-03$

Publication date:May $31^{\text {st }} 2021$

\section{Introduction}

Globally, urbanisation is growing due to population growth and rural-urban migration is one of the main reason and expansion of urbanization, it was also a man-made phenomenon with inbuilt activity on the environment and natural resource, in addition, the intervention of humans in the natural environment influences the nature of ecosystem processes by the rate at which they operate on the environment especially farmland around the urban area (Angel et al., 2011; Jiang, 2015). one of its main factor which is deforestation, the removal of land cover vegetation into the extent that human need to have residence. According to United Nations Human Settlements Programme, 54.5 per cent of the world's population resided in urban settings in 2016 based on this report by 2030, urban areas are projected to accommodate $\mathbf{6 0}$ per cent of the world population, and the urban population of developing countries will in increase with frequency of $\mathbf{2}$ per cent $(\mathbf{U N}, \mathbf{2 0 1 6})$ In other words, urbanisation can be defined as the transformation of forest and urban farmland to residential area and shifting cultivation area to urbanisation (FAO/UNEP, 1982). However, this definition does not include "logging". More inclusive was Myers's 1980 definition, where deforestation refers, "generally to the destruction of forest cover through clearing for agriculture land so that not a tree remains, and the land is given over to non-forest purposes and was] very heavy and unduly negligent logging results in a decline of biomass and depletion of ecosystem services So severe that the residual forest can no longer qualify as forest in any practical sense of the environment." Based on this idea this study was focus on the impact of human operation through expanding urban residential area on urban farmland a case Wolayta sodo city south Ethiopia. Human beings are highly dependent on the natural environment for their livelihoods, However, in the 21 st century, the impact of environmental variability and climate change has significantly affected the livelihoods of the poor and marginal societies in developing countries. For this study, the FAO's latest definitions (1993) will be used and (FAO 2012) defines forests as "ecosystems with a minimum of $10-20 \%$ crown cover of trees and/or bamboo, generally associated with wild flora, wildlife, and natural soil conditions, and not subject to agricultural practices" and deforestation as a "change of land use with a depletion of tree crown cover to less than $10 \%$ crown cover". One of the major challenges in the study area is environmental degradation coming from population pressure, land use urban residential expansion in addition weak urban agricultural domestic crop production, a lack of market value chain 
with the low rank of integrated urban Agricultural technology transfer and inadequate input supply and marketing systems (Shiferaw \& Singh, 2010)

This study is a reflection of human intervention urban Agricultural land and degradation in regarding to residential land and the studies made in this site may have wider application to other highland regions of the country. But beyond this assumption, the impact of deforestation on urban Agricultural livelihoods was not scientifically studied in southern Ethiopia and their surrounding in particular land in Wolayta zone sodo zuria woreda, Therefore, the study focuses on an urban agricultural land-use change based on change detection analysis using Primate and secondary data source with integration to Geographic Information System based (GIS) overlay analysis to managing the negative impact on the geospatial environment in the context of Ethiopian ATP 2 goal of sustainable and balanced land use planning for agricultural economic development livelihood in the study area

\section{Ground factor of urbanization in Wolayta Sodo,zuria woreda}

Food close and Housing is a significant basic input of man king and also land is the most expensive resource in most developing county in Ethiopia, Wolayta is the most densely populated area due to the rapidly growing population in urban and ruler area of the study area (Barana B, Senbetie T \& Aklilu B, 2016 ). And also According to (Wolayta Sodo Municipal 2018/19), the right to adequate housing was enshrined in several international human rights instruments and has long been regarded as essential to ensuring the wellbeing and dignity of the human person. Housing Rights have been included in the most authoritative international statements regarding human rights. Ethiopia was also been a member of this worldwide agreements. It has also been locally indorsed commandments that may reply to the residential land demand of urban residents. Mainly Ethiopia proclaimed a contestable announcement, i.e., proclamation no.721/2011. The proclamation's contribution in solving the currently escalated urban housing demand needs (Kidus M. Gebrehiwot E, and Kahsay .G, 2017). And in addition to the fast growth of population, this issue supposed to be raising urban expansion for the demand of housing for urban residents

\section{Materials and Method}

Wolayta Zone sodo zuria woreda Administration is one of Southern Nations, Nationalities and Peoples Regional (SNNPR) State, Ethiopia (Figure 3.1). In addition, it has a total area of the city of 16569.06 hectares and It is located about $396 \mathrm{~km}$ Southwest of Addis Ababa. Its geographical extent is between $746338.79 \mathrm{~m}$ and $763697.57 \mathrm{~m} \mathrm{~N}$ latitude and between $351399.84 \mathrm{~m}$ and $368966.93 \mathrm{~m}$ E longitude with altitude ranging from 1400 to 2140 amsl (Ethiopian demography and health organization institute 2018). It has kifle ketema and kebels. Sodo zuria woreda is located from Northwest of "Boloss Sore", from Northeast of "Damote Gale", from Southwest in "Offa" and from South of "Humbo" in Wolayta Zone Administration of Ethiopia and according to (CSA 2007) demographic study Population projection in 2020 the city currently assumed to more than 350,000

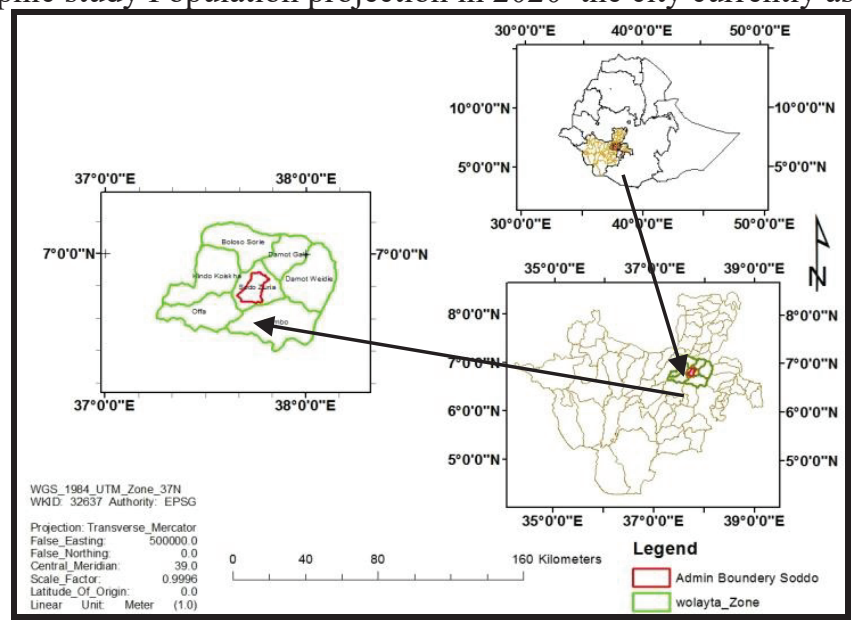

Fig 3.1. Location of the study area

\subsection{Materials}

Data for this study were collected from the local government Authority one of the offices was Ethiopian Mapping Authority (EMA) for coordinate transformation, Wolayta Sodo municipality for land use shapefile of 2010 and 2019 Land sat 7 (ETM+) satellite image of an average spatial resolution taken on 09/ July 2019, from path/row 169/55 from USGS as user Registry of Bereket for cross-checking information. The image was recorded on 6 bands, with a spatial resolution of 30 meters, while band 6 has. The radiometric resolution of the image was 8 bits and it was extracted by mask in Spatial Analysis by using study area boundary shapefile 
Table 3.1 Data and their sources

\begin{tabular}{|c|c|c|c|}
\hline Data Types & Sources & Specifications of data & Use of the data \\
\hline Satellite image & $\begin{array}{l}\text { Ethiopian } \\
\text { Mapping } \\
\text { Authority } \\
\text { (EMA) }\end{array}$ & $\begin{array}{l}\text { Image from Sep/2010 to } \\
\text { July/2010 } \\
\text { land sat } 7(\mathrm{ETM}+) \\
\text { Band_6 Resolution 30m } \\
\text { Datum D_WGS_1984 } \\
\text { And Image from Sep/2019 } \\
\text { to July/2019 }\end{array}$ & $\begin{array}{l}\text { Image classification } \\
\text { To see the difference of these single image } \\
\text { bands or raster layers of its } 6 \text { bands of raster } \\
\text { layer with the Image from Sep/2017 to } \\
\text { July/2017 } \\
\text { land sat (ETM }+ \text { ) }\end{array}$ \\
\hline Satellite image & $\begin{array}{l}\text { Ethiopian } \\
\text { Mapping } \\
\text { Authority } \\
\text { (EMA) }\end{array}$ & $\begin{array}{l}\text { Image from Sep/2017 to } \\
\text { July/2017 } \\
\text { Land sat (ETM+) } \\
\text { Band_6 Resolution 30m } \\
\text { Datum D_WGS_1984 }\end{array}$ & $\begin{array}{l}\text { For post Image classification } \\
\text { To see the difference of these single image } \\
\text { bands or raster layers of its } 6 \text { bands of raster } \\
\text { layer Image from Sep/ } 2010 \text { to July/2010 } \\
\text { Land sat (ETM+) }\end{array}$ \\
\hline $\begin{array}{l}\text { Land use land } \\
\text { cover }\end{array}$ & $\begin{array}{l}\text { Wolayta sodo } \\
\text { Municipality }\end{array}$ & $\begin{array}{l}\text { ESRI polygon land use } \\
\text { Shapefile Format }(* . s h p)\end{array}$ & To Analysis basic spatial change \\
\hline $\begin{array}{l}\text { Administrative } \\
\text { Boundary of } \\
\text { the study area }\end{array}$ & $\begin{array}{l}\text { Wolayta sodo } \\
\text { Municipality }\end{array}$ & $\begin{array}{l}\text { ESRI polygon Shapefile } \\
\text { format }(* \text {.shp) }\end{array}$ & $\begin{array}{l}\text { For spatial relationship remark concerning urbat } \\
\text { farm change }\end{array}$ \\
\hline
\end{tabular}

\section{Methodology of the research}

Land Sat $7(\mathrm{ETM}+)$ satellite image with GIS datasets existing land use, forest cover, the livelihood of study area administrative boundaries and village locations) with the resolution of $30 \mathrm{~m}$ has been used for this study and GIS data is based on information ranging from September 2010 to July 2019 over 9 years old to data was being processed for Change detection Analysis the main source for those satellite image was taken from Ethiopian Mapping Authority (EMA) in Image Analysis in Arc GIS 10.4.1 and Land sat 7 (ETM+) image preprocessing used in this study involve bright corrections, image enhancement, radiometric, atmospheric and geometric corrections applied to all bands, except the thermal band (Y,L., Newlands, davidson, A Zhang, Y., et al 2014). Radiometric corrections consisted of changing 8-bit digital values into radiance and reflectance values (Markham, B.L., Barker, J.L.1986) Land sat (ETM+7) satellite image was classified by using the supervised classification method and the algorithms maximum likelihood, Mahalanobis distance and minimum distance. This was done with the help of all bands found to be most effective in distinguishing each class, excluding the thermal band. The method consisted in choosing the training sites, the actual classification and result evaluation (Iosife V., Mihaela D., Publicity A., et al 2012)

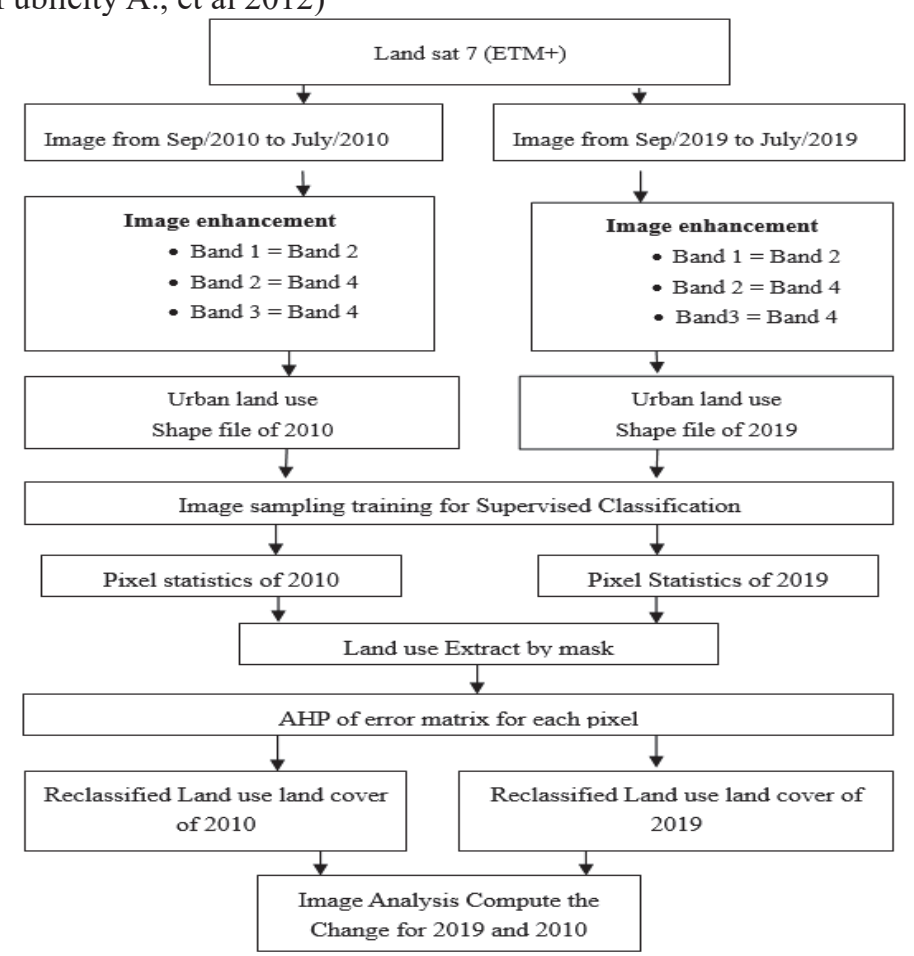

Fig 4.1 Technological scheme of study design 


\subsection{Data analysis, results and discussions}

As some scholars like (Wubante et al., 2019) indicated in their study, the demand for land for urbanization is primarily met by converting rural land through expropriation. However, land expropriations are adversely affecting the previous land users by reducing the amount of crop production and their sources of income and also supervising Urbanization expansion rate with the help of two different land sat7 (ETM+) image obtains different dates for the expansion rate (Ramada E., 2003)

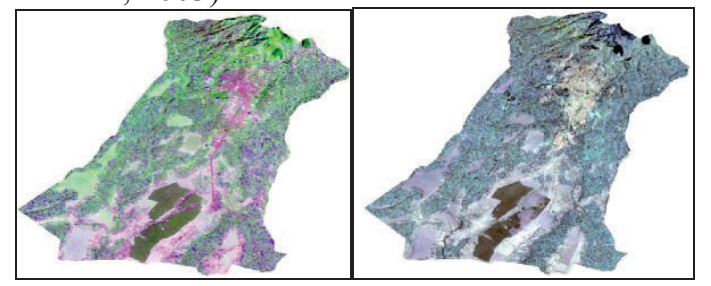

Fig 4.2 Land Sate 7 (ETM+) image 2010 and 2091 Source (EMA)

\subsection{Supervised classification}

According to (Peter E, 2018) in his GIS image analysis for change detection Analysis, used to perform image algebra on normalized difference vegetation index or NDVI button is used to perform image algebra on the red (band 3 for Land sat 7 ETM+) and near-infrared (band 4 for Land sat 7 ETM+) bands of an image to produce a new single band layer that shows "greenness" or relative biomass brighter (higher) value indicates a higher percentage of vegetation, healthier vegetation, or plant species differences. The formula for the calculation is NDVI = (IR - R)/(IR + R). (Y,L., Newlands, davidson, A Zhang, Y., et al 2014) however this study mainly focus urbanization change rather than NDVI and this study has used land-use shapefile of land use land cover data analysis of both 2010 and 2019 image the main source of the data for ground truth land cover data was Wolayta sodo municipality based on the information provided, this study has overplayed this shapefile to those two images for further analysis supervised classification applied to the three algorithms, namely: maximum likelihood, Mahalanob was distance and minimum distance. The maximum likelihood algorithm is one of the most widely used in the classification of satellite imagery (Vorovencii, 2005) according to this principle, this study has used land use land cover shapefile of 2010 (See fig 4.3 A) with delegated administrative boundary and it was overlaid to land sat TM 7 satellite image of 2010 that was a mask in spatial analysis tool by the boundary of 2019 (See fig 4.3 B) and accordingly supervised image classification with training sapling has done for postclassification (see fig $4.3 \mathrm{C}$ ) and in this analysis

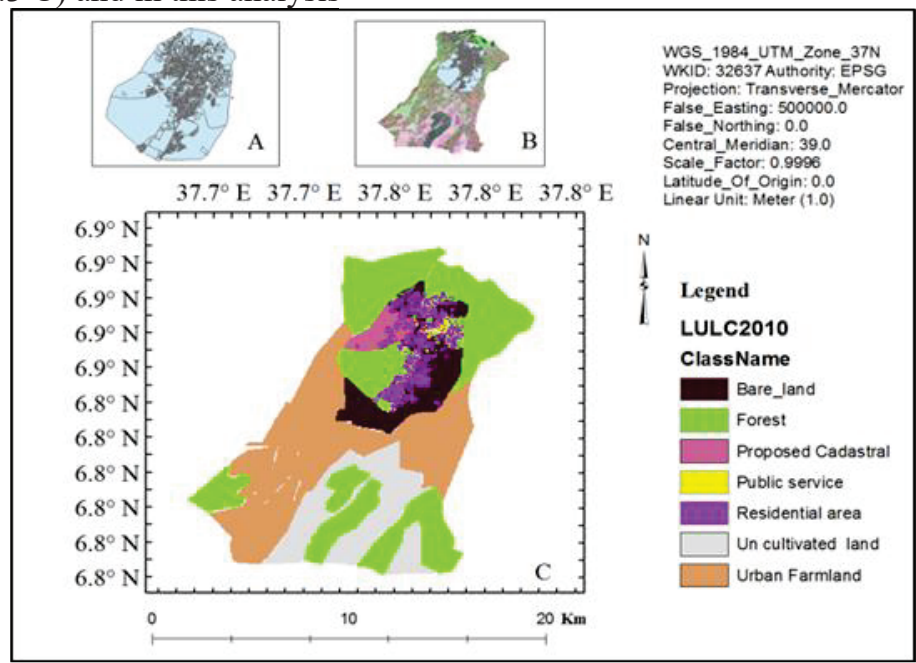

Fig 4.3 Reclassified land use land cover of 2010 (Source author2019)

According to Wolayta sodo municipality 2010 urban land use planning, the existed ground truth of land covers in 2010 has been generalized for seven major classes and the above-supervised classification was done as the seen table below consisted in choosing the training sites, the actual classification and result evaluation by Eagan Vector Matrix by AHP approach (Lilles and Kiefer, 1999). During the training phase, 80 training sites were selected which was original detail GIS shapefile land use land cover data of (Wolayta sodo Municipal 2018/19) and screen extraction of specific required land use land cover polygon shapefile was generalized to 7 major classes spectral classes obtained in this way were transferred to "signature editor" of the classification module of Arc GIS 10.4.1 software of Image Analysis After choosing the spectral signatures edited with checking them, for the same spectral class, were combined into a single class. And used for image classification and that training field was assigned a number from (1 to 7) representing land cover classes (see table 4.1 below) 
Table 4.1 Major reclassified urban land use land cover of Wolayta sodo in 2010 for Image training Sampling (Source: Sodo Municipality urban land use Geodatabase)

\begin{tabular}{|c|c|c|c|c|c|c|c|c|}
\hline & $\begin{array}{l}\text { LULC class } \\
\text { name of } 2010\end{array}$ & $\begin{array}{l}\text { Class } \\
\text { value }\end{array}$ & $\begin{array}{c}\text { RED } \\
\text { Band(1) }\end{array}$ & $\begin{array}{l}\text { GREEN } \\
\text { Band(2) }\end{array}$ & $\begin{array}{c}\text { BLUE } \\
\text { Band(3) }\end{array}$ & Pixel & $\begin{array}{c}\text { LULC area } \\
\text { of in (ha) }\end{array}$ & $\begin{array}{c}\text { In } \\
\text { Percent } \\
(\%) \\
\end{array}$ \\
\hline 1 & Bare land & 125 & 168 & 112 & 0 & 15140 & 1362.53 & 8.22 \\
\hline 2 & Forest & 129 & 59 & 163 & 9 & 66188 & 5956.49 & 35.94 \\
\hline 3 & Proposed Cadastral & 132 & 241 & 111 & 215 & 4139 & 372.54 & 2.24 \\
\hline 4 & Residential area & 139 & 255 & 255 & 115 & 10681 & 961.28 & 5.80 \\
\hline 4 & Public service & 165 & 200 & 18 & 60 & 397 & 35.80 & 0.21 \\
\hline 6 & Urban Farmland & 167 & 130 & 130 & 130 & 59871 & 5388.05 & 32.51 \\
\hline \multirow[t]{5}{*}{7} & Uncultivated land & 168 & 225 & 225 & 225 & 27694 & 2492.34 & 15.04 \\
\hline & Sum & 1025 & & & & 184110 & 16569.06 & 100 \\
\hline & Main & 146.42 & & & & & & 14.28 \\
\hline & $\begin{array}{l}\text { Randomly equalized } \\
\text { points }\end{array}$ & 146 & & & & & & 14 \\
\hline & $\begin{array}{l}\text { Land Sat TM } 7 \\
\text { satellite image is } \mathbf{1 4 6} \\
\text { Number of pixels } \\
\text { correctly classified } \mathbf{1 4}\end{array}$ & & & & & & & \\
\hline & $\begin{array}{l}\text { It was calculated by d } \\
\text { mber of pixels in this clas } \\
\text { rectly classified pixels ( } \mathrm{s} \\
\text { s study, it was used a tota } \\
\text { essing image classificatio } \\
\text { rectly classified from the } \\
\text { rs' accuracy for the land } \\
\text { d by AHP analysis using } \\
\text { ically, the data which } \\
\text { ssification. In general, a } \\
\text { erated over the classifiec } \\
\text { o known as confusion ma }\end{array}$ & $\begin{array}{l}\text { viding th } \\
\mathrm{s} \text { value }( \\
\mathrm{m} \text { of ma } \\
\text { of } 146 \mathrm{p} \\
\mathrm{n} \text { for acc } \\
14 \text { pixels } \\
\text { lasses } \mathrm{w} \\
\text { the value } \\
\text { the class } \\
\text { set of re } \\
\text { image. }\end{array}$ & $\begin{array}{l}\text { number } \\
\text { w total). } \\
\text { diagonal) } \\
\text { ints randor } \\
\text { acy assess } \\
\text { elonging } \mathrm{t} \\
\text { the follow } \\
\text { per cent } \\
\text { ied image } \\
\text { rence shap } \\
\text { e relation } \\
\text { ngency tal }\end{array}$ & $\begin{array}{l}\text { pixels cor } \\
\text { erall Accu } \\
\text { y the total } \\
\text { y equalize } \\
\text { ent of clas } \\
\text { each class, } \\
\text { g used in } \\
\text { ith geogra } \\
\text { was comp } \\
\text { file has be } \\
\text { ip betweer }\end{array}$ & $\begin{array}{l}\text { tly classi } \\
\text { m is calct } \\
\text { mer of } t \\
\text { ication al } \\
\text { the case } \\
\text { study an } \\
\text { c data co } \\
\text { ed to ar } \\
\text { overlaid } \\
\text { ee two im }\end{array}$ & $\begin{array}{l}\text { ed in eac } \\
\text { ted by di } \\
\text { ted pixels } \\
\text { ass value. } \\
\text { rithms, } \\
\text { maximur } \\
\text { diagonal } \\
\text { idered to }\end{array}$ & $\begin{array}{l}\text { class value } \\
\text { ding the tota } \\
\text { Lilles \& Kief } \\
\text { hese points } \\
\text { ven the numb } \\
\text { likelihood al } \\
\text { gen Vector } \mathrm{A} \\
\text { accurate an } \\
\text { h based on } \\
\text { and-use clas } \\
\text { ssed in the e } \\
\text { cess (AHP) }\end{array}$ & $\begin{array}{l}\text { the total } \\
\text { umber of } \\
\text {, 2000) In } \\
\text { re used in } \\
\text { of pixels } \\
\text { rithm, the } \\
\text { trixes was } \\
\text { referential } \\
\text { upervised } \\
\text { which are } \\
\text { or matrix, }\end{array}$ \\
\hline
\end{tabular}

\subsection{Analytic Hierarchical Process}

Evaluation of classification accuracy can be defined as the process of comparing the classified image with geographic data considered to be accurate and referential typically, the data which the classified image was compared to ground-truth based on supervised classification. In general, a set of reference shapefile has been overlaid as 7 major land-use class which are generated over the classified image. The relationship between the two images is expressed in the error matrix, also known as confusion matrix or contingency table by using Analytic Hierarchical Process (AHP) (Saaty. T., 2004) method employs an Eigenvector matrix for accuracy of Principal Component Assessment (PCA) in addition to underlying scale with values from 1 to 9 to rate the relative preferences for two supervised classifications of the image Computed Eigenvector Matrixes, which is an output of the pairwise comparison matrix to produce the best fit set based on the pixel value land-use area listed (table 4.1 of column 9 land use Area in \% ) this value has been calculated by use GIS Attribute (table 4.1) of the above. 
Table 4.2 Pixel for land use land cover area of 2010 (source author2019)

\begin{tabular}{|c|c|c|c|c|c|c|c|c|c|}
\hline & $\begin{array}{l}\text { Land use } \\
\text { Class in } \\
2010 \\
\end{array}$ & $\begin{array}{l}\text { Bare } \\
\text { Land }\end{array}$ & Forest & $\begin{array}{l}\text { Proposed } \\
\text { Cadastral }\end{array}$ & $\begin{array}{l}\text { Residential } \\
\text { area }\end{array}$ & $\begin{array}{l}\text { Public } \\
\text { service }\end{array}$ & $\begin{array}{l}\text { Urban_- } \\
\text { Farmland }\end{array}$ & $\begin{array}{l}\text { Un captivated } \\
\text { Land }\end{array}$ & \\
\hline 1 & Bare land & 8.223367475 & & & & & & & \\
\hline 2 & Forest & 35.9495096 & 35.9495096 & & & & & & \\
\hline 3 & $\begin{array}{l}\text { Proposed } \\
\text { Cadastral }\end{array}$ & 2.248434825 & 2.248434825 & 2.248434825 & & & & & \\
\hline 4 & $\begin{array}{l}\text { Residential } \\
\text { area }\end{array}$ & 5.801701077 & 5.801701077 & 5.801701077 & 5.801701077 & & & & \\
\hline 5 & $\begin{array}{l}\text { Public } \\
\text { service }\end{array}$ & 0.216088816 & 0.216088816 & 0.216088816 & 0.216088816 & 0.216088816 & & & \\
\hline 6 & $\begin{array}{l}\text { Urban } \\
\text { Farmland }\end{array}$ & 32.51874162 & 32.51874162 & 32.51874162 & 32.51874162 & 32.51874162 & 32.51874162 & & \\
\hline 7 & $\begin{array}{l}\text { Uncultivated } \\
\text { land }\end{array}$ & 15.04215659 & 15.04215659 & 15.04215659 & 15.04215659 & 15.04215659 & 15.04215659 & 15.04215659 & \\
\hline & SUM & 100 & 91.77663253 & 55.82712293 & 53.5786881 & 47.77698703 & 47.56089821 & 15.04215659 & 100 \\
\hline
\end{tabular}

a method employs an Eigenvector matrix for accuracy of Principal Component Assessment (PCA) in addition to underlying scale with values from 1 to 9 to rate the relative preferences for two supervised classifications of the image Computed Eigenvector Matrixes (Eastman J. R.1997), which is an output of the pairwise comparison matrix to produce the best fit set based on the pixel value land-use area listed (table 4.2 of column 9 land use Area in \%) this value has been calculated by use GIS Attribute (table 4.2)

Table 4.3 Eigenvector matrixes of developed land use 2010 for Producers Accuracy assessment (Source author 2019)

\begin{tabular}{|c|c|c|c|c|c|c|c|c|}
\hline & $\begin{array}{l}\text { Land use } \\
\text { Class in } 2010\end{array}$ & $\begin{array}{l}\text { Bare } \\
\text { land }\end{array}$ & Forest & Proposed Cadastral & $\begin{array}{l}\text { Residential } \\
\text { area }\end{array}$ & $\begin{array}{l}\text { Public } \\
\text { Service }\end{array}$ & $\begin{array}{l}\text { Urban } \\
\text { Farmland }\end{array}$ & $\begin{array}{l}\text { Uncultivated } \\
\text { Land }\end{array}$ \\
\hline 1 & Bare Land & 8.223367475 & & & & & & \\
\hline 2 & Forest & 35.9495096 & 35.9495096 & & & & & \\
\hline 3 & Proposed Cadastral & 2.248434825 & 2.248434825 & 2.248434825 & & & & \\
\hline 4 & Residential Area & 5.801701077 & 5.801701077 & 5.801701077 & 5.801701077 & & & \\
\hline 5 & Public Service & 0.216088816 & 0.216088816 & 0.216088816 & 0.216088816 & 0.216088816 & & \\
\hline 6 & Urban Farmland & 32.51874162 & 32.51874162 & 32.51874162 & 32.51874162 & 32.51874162 & 32.51874162 & \\
\hline 7 & Uncultivated Land & 15.04215659 & 15.04215659 & 15.04215659 & 15.04215659 & 15.04215659 & 15.04215659 & 15.04215659 \\
\hline 8 & SUM & 100 & 91.77663253 & 55.82712293 & 53.5786881 & 47.77698703 & 47.56089821 & 15.04215659 \\
\hline 9 & Main each actor & 87.10672293 & 79.24150204 & 43.79339766 & 42.29707066 & 37.74888263 & 40.03981992 & 7.521078295 \\
\hline 10 & $\mathrm{~L}$ Max $=7.52$ & 1.841896725 & 2.089188415 & 2.406745054 & 2.820404361 & 3.342701464 & 3.760539148 & 7.521078295 \\
\hline 11 & Producers Accuracy (\%) & $98.15(\%)$ & $97.91(\%)$ & $97.59(\%)$ & $97.17(\%)$ & $96.65(\%)$ & $96.23(\%)$ & $92.47(\%)$ \\
\hline 13 & $(\mathrm{CR})=0.0866846382$ & & & & & & & \\
\hline
\end{tabular}

The number of rows and columns in the error matrix must be equal to the number of categories whose precision is being evaluated and the number of diagonal sum of each land-use class should be equal to 100 (Saaty. T., 2004) with an acceptable consistency ratio of consistency ratio (CR) indicates the probability that the matrix ratings has randomly generated. As a rule, a CR larger than 0.10 should be re-calculated and the result is a CR of 0.09, which indicates a reasonable level of consistency in the pairwise comparisons (Saaty, T, 2004). The critical ratio of the calculated Eigen Vector Matrixes (EVM) for the PCA of this study was 0.08 (see table above 4.3) of row 13, which is acceptable 


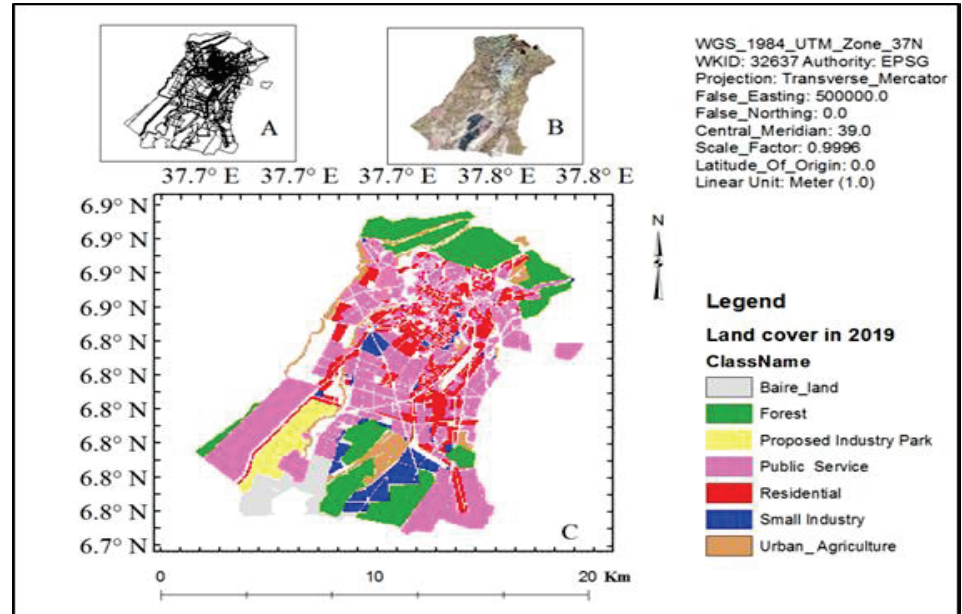

Fig 4.4 Reclassified land use land cover of 2019 (Source author 2019)

landcover shapefile of 2019 (See fig 4.3 A) with delegated administrative boundary and it was overlaid to land sat 7 (ETM+) satellite image 2019 and that was a mask in spatial analysis tool by the boundary of 2019 (See fig $4.4 \mathrm{~B}$ ) and accordingly supervised image classification with training sapling has done for post-classification (see fig $4.4 \mathrm{C}$ ) and in this analysis

Table 4.4 Pixel for land use land cover area of 2019 (Source author 2019)

\begin{tabular}{|c|c|c|c|c|c|c|c|c|}
\hline & $\begin{array}{l}\text { LULC Class } \\
\text { name in } 2019\end{array}$ & Class value & RED Band & GREEN Band & BLUE Band & Pixel Count & $\begin{array}{l}\text { Land/U } \\
\text { in (ha) }\end{array}$ & $\begin{array}{l}\text { Land covers } \\
\text { Area in (\%) }\end{array}$ \\
\hline 1 & Forest & 54 & 56 & 168 & 0 & 32268 & 2904.56 & 21.72 \\
\hline 2 & Public Service & 1658 & 255 & 85 & 0 & 61145 & 5447.91 & 41.16 \\
\hline 3 & Small Industry & 102 & 41 & 89 & 187 & 8341 & 754.46 & 5.62 \\
\hline 4 & Residential & 84 & 255 & 255 & 190 & 21697 & 1997.84 & 14.60 \\
\hline 5 & Urban_Agriculture & 1535 & 115 & 76 & 0 & 10694 & 966.35 & 7.19 \\
\hline 6 & Bare land & 1536 & 178 & 178 & 178 & 7800 & 700.87 & 5.25 \\
\hline 7 & Proposed Industry Park & 1665 & 169 & 0 & 230 & 6601 & 594.15 & 4.44 \\
\hline 8 & SUM & 6634 & & & & 148546 & 13366.187 & 100 \\
\hline 9 & Main & 947.71 & & & & & & 14.29 \\
\hline 10 & $\begin{array}{l}\text { Randomly equalized points } \\
\text { over } 2019 \text { Land Sat TM } 7 \\
\text { satellite image is } 978\end{array}$ & 978 & & & & & & \\
\hline 11 & $\begin{array}{l}\text { Number of pixels correctly } \\
\text { classified }\end{array}$ & 14.29 & & & & & & \\
\hline
\end{tabular}


Table 4.5 Eigen vector matrixes of developed land use 2019 for Producers Accuracy assessment (Source author 2019)

\begin{tabular}{|c|c|c|c|c|c|c|c|c|}
\hline & $\begin{array}{l}\text { Land use } \\
\text { Class in } 2019\end{array}$ & Forest & $\begin{array}{l}\text { Public } \\
\text { Service }\end{array}$ & $\begin{array}{l}\text { Small } \\
\text { Industry }\end{array}$ & $\begin{array}{l}\text { Residential_ } \\
\text { Area }\end{array}$ & Urban_Agriculture & $\begin{array}{l}\text { Bare } \\
\text { Land }\end{array}$ & $\begin{array}{l}\text { Proposed } \\
\text { Industry } \\
\text { Park }\end{array}$ \\
\hline 1 & Forest & 21.72256405 & & & & & & \\
\hline 2 & Public Service & 41.16233355 & 41.16233355 & & & & & \\
\hline 3 & Small Industry & 5.615095661 & 5.615095661 & 5.615095661 & & & & \\
\hline 4 & Residential & 14.60624992 & 14.60624992 & 14.60624992 & 14.60624992 & & & \\
\hline 5 & Urban Agriculture & 7.199116772 & 7.199116772 & 7.199116772 & 7.199116772 & 7.199116772 & & \\
\hline 6 & Bare land & 5.250898712 & 5.250898712 & 5.250898712 & 5.250898712 & 5.250898712 & 5.250898712 & \\
\hline 7 & Proposed In Park & 4.44374133 & 4.44374133 & 4.44374133 & 4.44374133 & 4.44374133 & 4.44374133 & 4.10014133 \\
\hline 8 & SUM & 100 & 78.27743595 & 37.1151024 & 31.50000673 & 16.89375681 & 9.694640042 & 3.00094123 \\
\hline 9 & Main & 96.19107886 & 74.57431817 & 33.56010933 & 28.16720074 & 13.93126259 & 7.472769377 & 4.10014133 \\
\hline 10 & $\mathrm{~L} \max$ & 0.544131591 & 0.617186296 & 0.710998613 & 0.833201499 & 0.987498073 & 1.110935333 & 7.10108256 \\
\hline 11 & (CR) for each & 0.005441316 & 0.006171863 & 0.007109986 & 0.008332015 & 0.009874981 & 0.011109353 & 0.071010826 \\
\hline 12 & Producers Accuracy (\%) & $99.45(\%)$ & $99.38(\%)$ & $99.28(\%)$ & $99.16(\%)$ & $99.01(\%)$ & $98.88(\%)$ & $92.89(\%)$ \\
\hline 13 & (CR) & 0.016847093 & & & & & & \\
\hline
\end{tabular}

\subsection{Analysis of overall accuracy assessment for supervised classification}

After applying the AHP algorithms, two thematic images obtained, showing the 7 land cover categories considered to be representative of the area under study (Fig.4.3\&4.4). The supervised classification method applied with the help of the provided land use land covers geospatial data of the study area from the city led to different results highlighted in the error matrix (Djenaliev, A. K, 2007). Thus, in the case of maximum likelihood, overall classification accuracy assessment obtained, for 2010 land sat 7 (ETM+) satellite image, AHP Eigenvector matrixes of developed land use 2019 for Producers Accuracy assessment followed by correlation was summarized as follow (Table 4.6) below with standard consistency ratio of 0.08 which acceptable

Table 4.6 Summarized Eigenvector matrixes result for 2010 land sat 7 (ETM+) satellite image (Source author 2019)

\begin{tabular}{clc}
\hline no & Land use/ land cover & Score in (\%) \\
\cline { 2 - 2 } $\mathbf{1}$ & Bare land & 98.15 \\
$\mathbf{2}$ & Forest & 97.91 \\
$\mathbf{3}$ & Proposed Cadastral & 97.59 \\
$\mathbf{4}$ & Residential area & 97.17 \\
$\mathbf{5}$ & Public Service & 96.65 \\
$\mathbf{6}$ & Urban Farmland & 96.23 \\
$\mathbf{7}$ & Uncultivated land & 92.47 \\
(CR) & Over all consistency ratio & $\mathbf{0 . 0 8 7}$ \\
\hline
\end{tabular}

and for specified 2019 land sat $7(\mathrm{ETM}+)$ satellite image, the number of pixels correctly classified from the 14 pixels belonging to each class, in the case of maximum likelihood algorithm, the users' accuracy for the land classes of Randomly equalized 978 points (see table 4.7) below

Table 4.7 Summarized Eigen vector matrixes result for 2019 land sat 7 (ETM+) satellite image (Source author 2019)

\begin{tabular}{|c|c|c|}
\hline no & Land use/land cover & Accuracy Assessment Score in (\%) \\
\hline 1 & Forest & 99.45 \\
\hline 2 & Public Service & 99.38 \\
\hline 3 & Small industry & 99.28 \\
\hline 4 & Residential area & 99.16 \\
\hline 5 & Urban Agriculture & 99.01 \\
\hline 6 & Bare land & 98.88 \\
\hline 7 & Proposed industry park & 92.89 \\
\hline (CR) & & 0.017 \\
\hline
\end{tabular}

The basic problem about Principle Component Assessment in transformation is to estimate the distributive matrix of multivariate random variables exactly and make clear the Eigenvalue and eigenvector of distributive 
matrix only based on band collations then original data is used to create linear conversion by regarding eigenvector as transform matrix only without considering ground land use geometry (He D.,Cai J., Zhou J., Wang Z., 2008 ) therefore this study was used AHP eigenvector matrixes algorithm rather than applying PCA for evaluation of classification accuracy that can be defined as the process of comparing the classified image with ground truth for different environmental impact assessment

\section{Results and discussion}

The results of the LULC classification for the time series of 2010 to 2019 were presented in (table 4.3 and 4.4) of this study based on this classification and AHP based eigenvector error matrix for accuracy assessment resulted in 0.087 of 2010 land sat $7(\mathrm{ETM}+)$ image of the study area and 0.017 of 2019 image classification and according to (Saaty.T., 2004, Haas, R., \& Meixner, N. 2016.) CR should be less than 0.10 to be acceptable and using Arc Toolbox $>$ Spatial Analyst Tools $>$ Math $>$ Minus tool with the layer as Input Raster value in GIS tools to see the changes in the urbanizing area between the two satellite image of 9 years. the values range from (6 to -4$)$ and are the class values assigned to the original colour map (fig 4.4) below as (Peter E, 2018) a (+ 6) indicates very fast a 90 to $100 \%$ spatially increase in urbanization between the years, a 0 equals no change and a (-4) indicates a 90 to $100 \%$ loss change in the area. This is a very significant result for the Wolayta sodo city and it was finally reclassified based on yearly sprawl data (see fig 5.1)

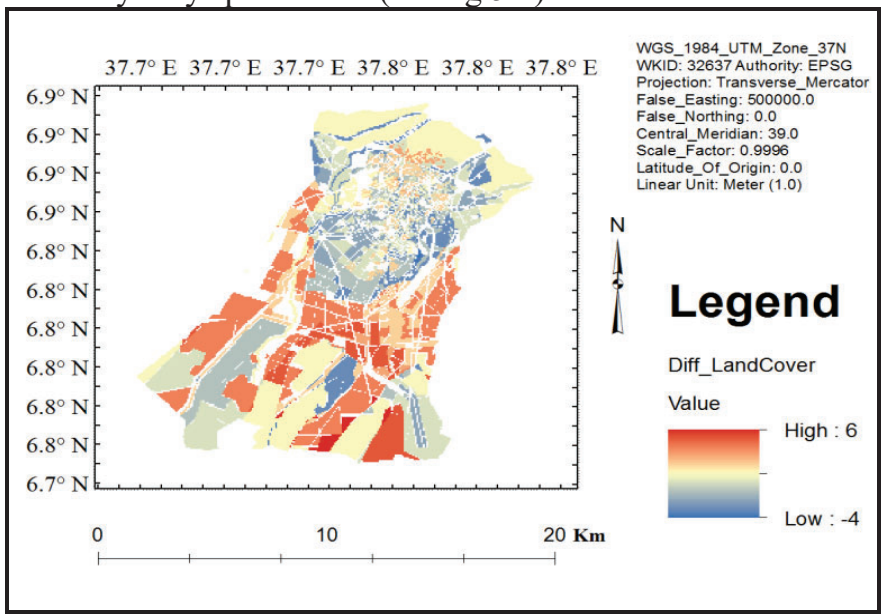

Fig 5.1 Change detection outcome of the study (Source author 2019)

As the analysis indicates $(+6)$ indicates a 90 to $100 \%$ increase in urbanization land cover between the 9 years, a (0 to 1) equals no change, and (-4) indicates a 90 to $100 \%$ Forest, Farmland, Bare land and uncultivated land loss and as this very significant result for the study area, this research can equate tree loss or gain to processes associated with the urban development of the study area with the rate of change formula and the outcome was reclassified spatially for 5 ranking score (Haas, R. and Meixner N., 2016) as seen fig 5.2 below as final result of the study

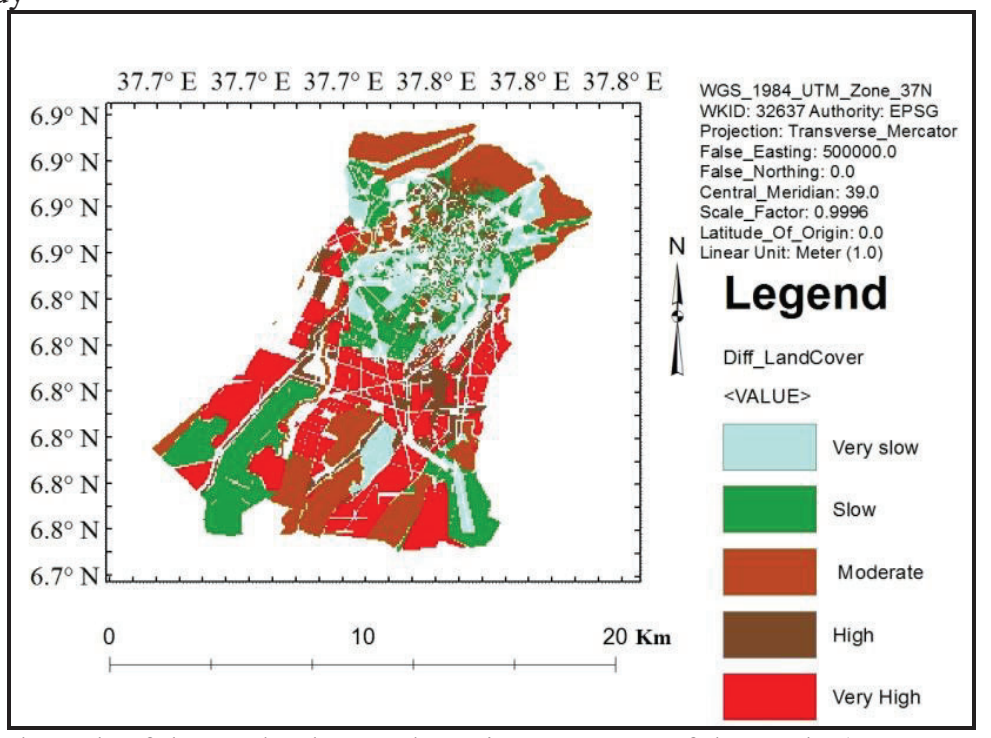

Fig 5.2 Final result of the study change detection outcome of the study (Source author 2019)

While the actual cause of change has been detected as +6 and -4 at (fig 6) of this study for the two images, 
the outcome of the analysis areas of each land use/ land cover for 2010 and 2019 was computed from Land sat7 $(\mathrm{ETM}+)$ images, the corresponding areas for each LULC between years were calculated by multiplying the area of individual LULC by the annual rate of change. This latter measure was obtained using equation (Alemayehu A., Assefa A., Asmamaw L.,\& Diogenes L.2016.)

$$
\mathrm{r}=\left(l_{2}-l_{1} / l_{2} \times 100\right) / t \ldots \ldots \ldots . \text { eq } 1
$$

where: ' $r$ ' is the mean annual rate of LULC change for a given study period, L2 and L1 are LULC areas (ha) in 2010 and 2019 from (table 4.3 and 4.4) of this study, respectively and ' $t$ ' is the interval year between 2010 and 2019 ( 9 years)

Table 5.1 Detail spatial sprawl between 9 years (Source author 2019)

\begin{tabular}{|c|c|c|c|c|c|c|}
\hline no & & LULC2010 & $\begin{array}{l}\text { LULC2010 } \\
\text { area in (ha) }\end{array}$ & $\begin{array}{l}\text { LULC } \\
2019\end{array}$ & $\begin{array}{l}\text { LULC2019 } \\
\text { area in (ha) }\end{array}$ & Change \\
\hline & 1 & Bare land & 1362.535078 & Forest & 2904.560059 & -0.5308979 \\
\hline & 2 & Forest & 5956.497505 & Public Service & 5447.919922 & 0.09335261 \\
\hline & 3 & Proposed Cadastral & 372.5446209 & Small Industry & 754.4689941 & -0.50621612 \\
\hline & 4 & Residential area & 961.2876052 & Residential & 1997.849976 & -0.51883894 \\
\hline & 5 & Public service & 35.80389575 & Urban Agriculture & 966.3599854 & -0.96294973 \\
\hline & 6 & Urban farmland & 5388.05134 & Bare land & 700.8729858 & 6.68762878 \\
\hline & 7 & Uncultivated land & 2492.344657 & Proposed Industry Park & 594.1550293 & 3.19477162 \\
\hline Sum & & & 16569.0647 & & 13366.18695 & 23.96253892 \\
\hline
\end{tabular}

Table 5.2 Summer for Urbanization change rate of Wolayta sodo town of 9 years(Source author 2019)

\begin{tabular}{cccccc}
\hline & No & LULC 2010 & $\begin{array}{c}\text { LULC } \\
\mathbf{2 0 1 9}\end{array}$ & Change & Rate in (\%) \\
\hline & $\mathbf{1}$ & 1362.5351 & 2904.56006 & \\
$\mathbf{2}$ & 5956.4975 & 5447.91992 & \\
$\mathbf{3}$ & 372.54462 & 754.468994 & \\
& $\mathbf{4}$ & 961.28761 & 1997.84998 & \\
& $\mathbf{5}$ & 35.803896 & 966.359985 & & \\
& $\mathbf{6}$ & 5388.0513 & 700.872986 & & \\
& $\mathbf{7}$ & 2492.3447 & 594.155029 & $\mathbf{2 3 . 9 6 2 5 4}$ & $\mathbf{2 . 6 6}$ \\
\hline
\end{tabular}

\section{Conclusion}

As different scholars investigated, (Alemayehu A., Assefa A., Asmamaw L.,\& Diogenes L. 2016 ) should be analysed by each spatially related sprawl and this study also identified changes in land-use/land cover and the relationship with a growing sprawl of urbanization in Wolayta Sodo city (Southwestern Ethiopia) for the period between 2010 and 2019. The study also showed that urbanization increased by approximately $2.66 \%$ of 9 years which is $0.295 \%$ per year while forestland declined by about $0.09 \%$ for the land has used for public service during the selected study period and also urban farmland become bare land by $6.7 \%$ this was estimated as crop production loses in domestic Agricultural livelihood and 3.2 \% of the area has proposed for industry zoning by the municipality As we can see from the above table urbanization rates with $2.66 \%$ every year according to the equation adopted above (Ningal et al. 2008; FAO 2012), urbanization rate was $2 \%$. And also according to the 1999/2000 agricultural sample survey conducted by the Central Statistical Authority (CSA), the average farm size for the total country is 0.97 hectare whereas 29 per cent of the total farming households have half or less hectare of land (CSA, 2007). In the areas of the Sothern highlands of Ethiopia,

\section{References}

Alemayehu A., Assefa A., Asmamaw L.,\& Diogenes L. 2016. Population growth and other factors affecting land-use and land-cover changesin north-eastern Wollega, Ethiopia. Article in Tropical Agriculture October 2016

Angel, S., Parent, J., Civco, D.L., Blei, A., Potere, D., 2011. The dimensions of global urban expansion: estimates and projections for all countries, 2000-2050. Prog. Plann. 75(2), 53-107 
Barana B, Senbetie T \& Aklilu B, 2016. Land use/Land Cover Dynamics and its Implication on Sustainable Land Management in Wallecha Watershed, Southern Ethiopia. Wolayta Sodo University, Global Journal of Science Frontier Research: H Environment \& Earth Science Volume 16 Issue 4 Version. (USA) Online ISSN 2249-4626 \& print ISSN 0975-5896

CSA. The 2007 population and housing census of Ethiopia: results for Wolayta soddo Provisional Administration. statistical report. Central Statistics Authority. Addis Ababa, Ethiopia. Page 7

Djenaliev, A. K, 2007. Multi criteria decision making and GIS for railroad planning in Kyrgyzstan Master's of Science Thesis in Geoinformatics TRITA-GIT EX 07-007. School of Architecture and the Built Environment Royal Institute of Technology (KTH) 10044 Stockholm, Sweden

ESRI 2019. ArcGIS 10.4.1 Help, 2004. Online Manual. Environmental System Research Institute Inc., Redlands, California

Eastman J. R.1997. Idrisi for Windows, Version 2.0: Tutorial Exercises, Graduate School of Geography - Clark University, Worcester, MA.England.

FAO. 2012. Food and Agricultural Organizations of the United Nations. 2012. Global forest land-use change 1990-2005. Forestry Paper No.: 169. Rome: FAO

Haas, R. and Meixner N., 2016. An Illustrated Guide to the Anlytic Hierarchy Process. Institute of Marketing \& Innovation, University of Natural Resources and Applied Life Sciences, Vienna [Available online] http://www.boku.ac.at/mi/

He D., Cai J., Zhou J., Wang Z., 2008. Urban Change Detection of Integrating Remote Sensing and GIS Taking Tianjin City. institute of Remote Sensing Applications Chinese academy of sciences, ; https://www.researchgate.net/publication/266521085

Iosif V., Mihaela D., Publicity A., et al 2012. Evaluation of supervised classification algorithms for Landsat 5 TM images, University of Transilvania Braşov, Romania https://www.researchgate.net/publication/313584971

Iosif V., Mihaela D., Publicity A., et al 2012. Vorovencii, I. Researches Concerning the Possibilities of Using Satellite Images in Forest Planning Works. Doctor's degree paper. "Transilvania” University of Brasov, 294 p, 2005 Wolayta, S. M, 2010. department of urban land use planning and management, Annul Report 2009/2010. 15 June 2010. Urban land Audit report

Kidus M. Gebrehiwot E, and Kahsay .G, 2017. Assessing Urban Lands Lease Holding Proclamation No.721/2011 in Addressing Housing Demand of Urban Residents and Rent Seeking Practices: The Case of Wolaita Zone. Wolayta Sodo University School of low

Lillesand, T.M., Kiefer, R.W. 1987 - Remote Sensing and Image Interpretation. John Wiley \& Sons, Inc. New Jersey, 1999

Markham, B.L., Barker, J.L.1986. Landsat MSS and TM post-calibration dynamic ranges, exoatmospheric reflectances and at-satellite temperatures. Earth Observation Satellite Co., Lanham, MD, Landsat Tech. Note 1, 1986

Ningal, N., A.E. Harteminka, and A. K. Bregt. 2008. "Land use change and population growth in the Morobe Province of Papua New Guinea between 1975 and 2000.” Journal of Environmental Management 87(1): 117-124

Peter E , 2018, Manual for Image Analysis with Arc GIS 10.4.1 for Environmental Change detection Analysis. The University of British Columbia Department of Geography ancouvar Campus.www.geog.ubc.ca material downloaded data 4/July/2019 5.05 AM

Ramada E., 2003. Monitoring of Urban growth based on Change in NDVI and Texture A case of Shaoxing city Zhejiang provice. Journal of Remote sensing information

Saaty, T, 2004. The Analytic Hierarchy Process. McGraw-Hill, New York ,1980, pp. 20-25. www.satecs.com.,Some words on the Analytic Hierarchy Process (AHP) and the provided ArcGIS extension 'ext_ahp

UN, 2016. Department of Economic and Social Affairs, Population Division the World's Cities in 2016-Data Booklet (ST/ESA/ SER.A/392)

Y,L., Newlands, davidson, A Zhang, Y., et al 2014. Assessing the Performance of MODIS NDVI and EVI for seasonal Crop Yield forecasting at the Ecodistrict Scale, Remote Sensing. online 6(10), 10193-10214

Wolayta Zone Soddo Municipality Department of beautification and sanitation agency, Annul Report 2002/2003EC. . 15 May 2018/19

Wubante F., Admasu A., Steven V., Passel b,c, Amare S., Minale D., Enyew A., Tsegaye E., Hossein A., Jan N., An economic assessment of land expropriation for urban expansion in Bahir Dar, Northwest Ethiopia. Department of Land and Real Property Valuation, Bahir Dar University, Yibab campus, PO Box 5001, Bahir Dar, Ethiopia., Belgium journal homepage: www.elsevier.com/locate/landusepo 